NBER WORKING PAPER SERIES

\title{
FERRETING OUT TUNNELING: AN APPLICATION TO INDIAN BUSINESS GROUPS
}

\author{
Marianne Bertrand \\ Paras Mehta \\ Sendhil Mullainathan \\ Working Paper 7952 \\ http://www.nber.org/papers/w7952 \\ NATIONAL BUREAU OF ECONOMIC RESEARCH \\ 1050 Massachusetts Avenue \\ Cambridge, MA 02138 \\ October 2000
}

We thank Abhijit Banerjee, Simon Johnson, Tarun Khanna, Jayendra Nayak, Ajay Shah, Susan Thomas and seminar participants at the MIT Development Lunch, the Harvard/MIT Development Seminar, the NBERNCAER Conference on Reforms, and the HBS Conference on Emerging Markets for their useful comments. Mehta is also grateful for financial support from a National Science Foundation Graduate Fellowship. The views expressed in this paper are those of the authors and not necessarily those of the National Bureau of Economic Research.

(C) 2000 by Marianne Bertrand, Paras Mehta, and Sendhil Mullainathan. All rights reserved. Short sections of text, not to exceed two paragraphs, may be quoted without explicit permission provided that full credit, including (C) notice, is given to the source. 
Ferreting Out Tunneling: An Application to Indian Business Groups

Marianne Bertrand, Paras Mehta, and Sendhil Mullainathan

NBER Working Paper No. 7952

October 2000

JEL No. G3

\section{ABSTRACT}

In many countries, controlling shareholders are accused of tunneling, transferring resources from companies where they have few cash flow rights to ones where they have more cash flow rights. Quantifying the extent of such tunneling, however, has proven difficult because of its illicit nature. This paper develops a general empirical technique for quantifying tunneling. We use the responses of different firms to performance shocks to map out the flow of resources within a group of firms and to quantify the extent to which the marginal dollar is tunneled. We apply our technique to data on Indian business groups. The results suggest a significant amount of tunneling between firms in these groups.

Marianne Bertrand

Graduate School of Business

University of Chicago

101 East $58^{\text {th }}$ Street

Chicago, IL 60637

and NBER, CEPR

marianne.bertrand@gsb.uchicago.edu

Sendhil Mullainathan

Department of Economics

MIT

50 Memeorial Drive, E52-380A

Cambridge, MA 02173

and NBER

mullain@mit.edu
Paras Mehta

Department of Economics

MIT

50 Memorial Drive

Cambridge, MA 02173 


\section{Introduction}

While this may seem exotic from a US perspective, many firms in the world are organized into so-called pyramids. La Porta, Lopez-de-Silanes, Shleifer and Vishny (1999) find that approximately $25 \%$ of their sample firms are members of pyramids. In a pyramid, an ultimate owner uses indirect ownership to maintain control over a large group of companies. Figure 1 shows a stylized example. Here, the ultimate owner owns enough shares to control A (in this case assumed to be 20\%). Firm A, in turn, owns controlling shares in firm B, and so on. This chain of ownership allows the ultimate owner to control all the firms, even the ones in which he has no direct ownership. He, therefore, maintains control over all firms in the pyramid without being entitled to much of their cash flows. In Figure 1, for example, if firm D pays a dividend of a hundred dollars, 20 of these dollars go to firm C, five to firm B, and so on, diminishing to little more than thirty cents by the time it reaches the ultimate owner. This stark separation of ownership from control characterizes pyramids. ${ }^{1}$

This separation generates strong incentives for the ultimate owner to divert resources between firms in the pyramid. ${ }^{2}$ In the example above, it is in the owner's interest to divert one hundred dollars of D's profits to A and thereby transform a thirty cent gain into a 20 dollar gain. This diversion, which has been labeled tunneling, can take many forms (Johnson, La Porta, Lopezde-Silanes and Shleifer 2000). High (or low) interest rate loans, selling of inputs or purchase of outputs at non-market prices, leasing of assets, and guarantees of other companies' borrowing are only a few of the readily available ways to tunnel. During the emerging market crises of 1997-98, many alleged that tunneling was occurring via these means. ${ }^{3}$ If prevalent, tunneling can have large

\footnotetext{
1 By contrast, in a typical US firm (as well as in stand-alone firms in other countries), formal control and cash flow rights usually go hand in hand. Informal control and cash flow rights may diverge as in the case of a CEO who owns few of the shares in his firm. But shareholders always retain the formal control to remove the CEO or make other fundamental changes to the firm.

2 Bebchuk, Kraakman and Triantis (2000), Wolfenzon (1999), and Shleifer and Wolfenzon (2000) theoretically illustrate this form of minority shareholder expropriation. This problem contrasts with that of U.S. firms: extravagant spending or poor decisions (Berle and Means, 1934; Jensen and Meckling, 1976).

3 Johnson, Boone, Breach and Friedman (2000) showed, that countries with better legal protection against
} 
consequences. Because well-functioning capital markets require that outside shareholders benefit from their holdings, tunneling may raise a serious barrier to financial development. The very processes of transferring resources may also entail social costs. For example, tunneling may reduce the transparency of the entire economy, clouding accounting numbers and making it hard to infer the health of firms. ${ }^{4}$

These reasons highlight the need for quantifying the extent of tunneling. But this has been a notoriously difficult empirical task, since it is in the interest of the ultimate owners to tunnel in subtle and hard-to-detect ways. What evidence we do have does not single out tunneling. For example, it has been previously documented that firms higher up in a pyramid perform better (on measures such as q ratio or profitability). ${ }^{5}$ But this may be due to differences in managerial skills, pre-existing efficiency or any number of other unobservable factors. More broadly, this kind of evidence does not allow one to track the flow of resources between firms, the heart of tunneling.

This paper introduces a general procedure to quantify tunneling. This method can be easily understood by analogy with brain imaging techniques such as PET (Positron Emission Tomography) scans. The scanner tracks blood flow in the brain by following the path of radioactively tagged material, such as glucose, that has been injected into the blood. Similarly, we will follow the flow of money through the pyramid by tracking the propagation of exogenous shocks to different firms in the pyramid. ${ }^{6}$

In our example, consider a shock that should raise the profits of a pyramidal firm $\mathrm{X}$ by a hundred tunneling were less affected by the crisis.

4 It is worth noting that pyramids may add social value in other ways that offset the social costs they impose through tunneling. They might help reduce transaction costs, solve external market failures or provide reputational capital for their members. We will not, therefore, be attempting to test whether pyramids are on net bad, merely whether, and if so how much, they tunnel.

5 Examples of papers that have documented such differences include Bianchi, Bianco and Enriques (1999), Claessens, Djankov, Fan and Lang (1999), Claessens, Djankov and Lang (2000). A broader literature has studied groups more generally (Khanna and Palepu 2000, Hoshi, Kashyap and Scharfstein 1991). Others have documented differences in the price of voting and non-voting shares (Zingales 1995, Nenova 1999).

6 The side effects of this procedure are as of yet undetermined. 
dollars (for example, perhaps the profits of other firms in X's industry rise by this much). The propagation of this shock through the pyramid tells us the extent of tunneling. First, if money is tunneled out of $\mathrm{X}$, we expect its profits to rise by less than 100 dollars, the shortfall indicating the amount of extraction. Second, since tunneling ought to be more prevalent lower in the pyramid (where the ultimate owner's cash flow rights are weak), we would expect this shortfall to be larger the lower firm $\mathrm{X}$ is in the pyramid. In our example, we would expect a greater shortfall in $\mathrm{D}$ than in A. Third, we expect the recipients of tunneling to respond to the shocks of other firms in the pyramid. In our example, we would expect A to respond to D's shock. Notice the asymmetry in this relationship. D should not respond to A's shock. Moreover, if there were another firm at the same level as D, that firm would respond to neither A's nor D's shock. ${ }^{7}$ As long as we can measure industry shocks, firm performance, membership and position in the pyramid, we can translate these simple intuitions into regressions. ${ }^{8}$

As an illustration, we apply this test to earnings data for a panel of Indian firms between 1989 and 1999. Our results suggest that tunneling is quite prevalent in India. We find evidence for the full set of predictions above: group firms respond less than one-for-one to their shock, with "low" firms responding the least; "high" firms show more sensitivity to the shocks of other firms in the group, most notably to the shocks affecting lower firms. ${ }^{9}$ Moreover, our estimated magnitude of tunneling is large. For example, group firms are on average only $70 \%$ sensitive to their shock, while at the same time group firms at the top of their pyramid are completely sensitive.

Could these results be driven by something else than tunneling? First, one might be concerned

\footnotetext{
7 This distinction will be crucial when considering other theories of why shocks may propagate through a pyramid, most notably risk sharing.

8 Other papers have used shocks in a related way. Blanchard, La Porta and Shleifer (1994) examine how US firms respond to windfalls (winning a law suit) to assess agency models. Lamont (1997) uses the oil shock to assess the effects of cash flow on investment. Bertrand and Mullainathan (forthcoming) use several shocks to assess the effects of luck on CEO pay.

9 In India, pyramids are known as groups and hence we will use the terminology of "group" and "pyramid" interchangeably.
} 
that our results mechanically result from the actual flow of dividend payments between firms in the pyramid. Note to start that such a mechanical effect is theoretically unlikely. Not only does dilution make this effect small as one moves up the pyramid, it also implies that top firms should be less sensitive than middle firms to shocks affecting lower firms. We however check for this directly by excluding dividend payments from our earnings and find no change in the results. Another potential issue could arise if we have mismeasured a firm's industry: the greater the mismeasurement, the less the apparent sensitivity of a firm to its industry shock. This could problematic for our approach if mismeasurement were to follow the lines of control and be relatively more severe for lower down firms. Using detailed data on the array of products produced by each firm, we find no evidence that mismeasured industry classification drives our results. Note moreover that it would difficult to explain our entire set of results under this explanation. For example, why wouldn't bottom firms also be sensitive to top firms' shocks? ${ }^{10}$ Finally, perhaps co-insurance among firms produces this pattern of sensitivities. Clearly, simple insurance models could not explain the asymmetry of the flows, so a more complicated model - one in which firms at the top of their pyramid are providers of insurance to firms lower down — would be needed. We find little evidence in support of the co-insurance view. Top firms are not more cash rich (and therefore not better providers of insurance), nor does the flow of resources between firms appear targeted towards lower-cash-flow firms (i.e., those who would be in greater need of insurance). In Section IV.1, we discuss these and other possibilities in greater detail. As a whole, our findings appear strongly consistent with the tunneling view and cannot easily to reconcile with any other phenomenon.

Finally, we use our ability to isolate tunneling to answer two more questions. First, through what balance sheet items does tunneling occur? Using various decompositions, we find that most of

\footnotetext{
10 This alternative interpretation of our results would also have trouble explaining a fact we discuss below: most of the tunneling appears on non-operating profits, whereas operating profit measures show none or little of the differences in sensitivity.
} 
the tunneling appears on non-operating profits. Thus, for India at least, buying of inputs or selling of outputs at non-market prices does not appear to be an important means of tunneling. Second, does the market valuation reflect the extent of tunneling? Using simple q measures (market to book ratios benchmarked against industry, size and time) we find that firms with high q are indeed more sensitive to both their own shock and the group shock. Firms whose group has a high q are more sensitive to their own shock, but are no less (or very slightly less) sensitive to the group shock. These results suggest that equity prices at least partly incorporate the extent of tunneling.

The rest of the paper is organized as follows. Section presents a simple model of pyramidal firms and the test for tunneling implied by this model. Section II.2 describes the application to India and our results for this data set. Section III.6 describes alternative explanations and extensions. Section IV.3 concludes.

\section{Pyramids and Tunneling}

\section{II.1 A Model of Pyramids}

We begin with a simple model of pyramids that merely expands on Figure 1. Suppose there are $k=1, \ldots, N$ firms in the pyramid. The ultimate owner owns a fraction $d_{i}$ of company $i$, and each company $k$ owns a fraction $f$ in company $k+1$. Suppose the ultimate owner has enough shares to control the first company, that is $d_{1}>C$, where $C$ is the number of shares required for control. ${ }^{11}$ This means he can vote the shares of company 1 in company 2 and hence controls $d_{2}+f$ votes in company 2. Thus, in order to guarantee that he maintains control of the pyramid, we

\footnotetext{
11 Formal control can be thought of as $C=.5$. With $50 \%$ of shares, one can always win a proxy fight. Practically, though, real control may be exercised at lower levels, perhaps because of the advantage of toeholds. In India, for example, control for many purposes is defined as ownership of between $15 \%$ and $25 \%$ of the shares.
} 
further assume that $d_{k}+f>C$ for $k>1$. As is clear from this inequality, the ultimate owner is guaranteeing control though direct $\left(d_{k}\right)$ as well as indirect $(f)$ ownership.

Now, we turn to the cash flow rights of the ultimate owner in each firm $k$ of the pyramid, which we call $c_{k}$. Clearly, the cash flow right of the ultimate owner in firm 1 is just $d_{1}$. Now consider the cash flow right of the ultimate owner in firm $k$, where $k>1$. If firm $k$ pays one dollar in dividends, the owner gets $d_{k}$ directly in dividends, and $f$ dollars will flow to firm $k-1$. We can see that this logic generates the recursive formula:

$$
(\forall k>1) c_{k}=d_{k}+f c_{k-1}=\sum_{j=1}^{k} d_{j} f^{k-j}
$$

Each company $j$ located above $k$ gets some of $k$ 's profits. The ultimate owner's holdings in each $j$ give him a share in these profits. But notice the exponentially fast dilution. Company $k-1$ gets a fraction $f$ of $k$ 's profits, while company $k-2$ only gets a fraction $f^{2}$, and so on as we move up the chain.

The case where the ultimate owner has direct holdings only in the top firm $\left(d_{k}=0\right.$ for all $\left.k>1\right)$ will help clarify ideas. In this case, $c_{k}=d_{1} f^{k-1}$, and he receives an exponentially diminishing cash flow from each firm. This illustrates the fundamental problem of pyramidal structures: even though profits in low-down companies benefit the ultimate owner very little, he still controls them. In the general setup, we will require that $c_{k}>c_{k+1}$ to guarantee the same feature.

With these assumptions in place, we can now investigate tunneling. ${ }^{12}$ We begin with the idea that each firm $k$ has fundamental earnings $F_{k}$, the earnings that would occur in the absence of any tunneling. ${ }^{13}$ We assume a diversion technology such that if the owner diverts $D_{k}$ dollars from

\footnotetext{
12 This is a highly stylized model and, therefore, excludes many realistic details. There may be more than one company at each tier. A firm may own shares in firms other than those immediately below it. Companies may own shares in each other. These complications are easy to incorporate. Whatever the underlying structure, one need only order firms according to the ultimate owner's cash flow rights on that firm. The chain is merely a stylized representation of this ordering.

13 We assume that these are earnings net of dividend receipts.
} 
firm $k$, he will have $\lambda\left(\frac{D_{k}}{F_{k}}\right) F_{k}$ dollars to infuse into another company. We assume that $\lambda(\cdot)$ is an increasing, concave function that captures the idea that it is increasingly hard to divert larger fractions of a company's earnings. Letting $I_{k}$ be the amount of money diverted into company $k$, we can define observed earnings to be:

$$
E_{k}=F_{k}-D_{k}+I_{k}
$$

The controlling shareholder will then want to maximize his personal benefits:

$$
\begin{aligned}
\max _{D_{k}, I_{k}} & \sum_{k} c_{k} E_{k}=\sum_{k} c_{k}\left(F_{k}-D_{k}+I_{k}\right) \\
\text { s.t } & \sum_{j} I_{j} \leq \sum_{j} \lambda\left(\frac{D_{j}}{F_{j}}\right) F_{j}
\end{aligned}
$$

with the constraint arising because, in aggregate, he can't funnel more money into firms than he has diverted out.

The first order conditions for this problem generate several simple predictions:

1. Diversion will occur: $D_{k}>0$ for $k>1$.

2. The marginal dollar will be partly diverted: $\frac{\partial D_{k}}{\partial F_{k}}>0$.

3. Diversion as a whole and diversion of the marginal dollar will be more prevalent in low-down companies: $D_{k}$ and $\frac{\partial D_{k}}{\partial F_{k}}$ will be increasing in $k$.

4. Higher-up firms will receive more of this diversion: $I_{j}$ will be decreasing in $j .{ }^{14}$

5. The inflows mean that pyramidal firms will be sensitive to each other's fundamental earnings.

Higher-up firms are more responsive to the fundamental earnings of other firms in their

\footnotetext{
14 In fact, because we have not included any cost of funneling money into a firm (only costs of diverting money out) in our simple model, all money that is diverted will be diverted into the top firm only. Adding a convex cost $\gamma(\cdot)$ (analogue to $\lambda$ ) of funneling money into a firm would smooth this result. Interestingly, we will find in Section III. 6 that, in fact, the inflows of money do appear to flow mainly to the topmost firm.
} 
pyramid, and they will be most responsive to the fundamental earnings of lower firms. This implies that $\frac{\partial I_{j}}{\partial F_{k}}$ is decreasing in $j$ and increasing in $k$.

These results are extremely intuitive and merely capture the intuition that the ultimate owner will divert cash from the bottom to the top.

\section{II.2 A Test for Tunneling}

This framework lays out the logic of tunneling, but how to test for it? Suppose we could correctly measure the fundamental earnings of a firm, F. Then, we could readily test for tunneling. The difference between a firm's reported earnings and fundamental earnings, $E-F$, measures net diversion, which we could then relate to the firm's level in the pyramid, and so on. Of course, this merely reshapes the problem, since measuring $F$ may be as difficult as measuring diversion.

The starting point of our test is that while we may not be able to measure the level of fundamental earnings, we may be able to measure shocks to that level. To take a concrete example, suppose that the world price of gold rises, causing the gold industry's profits to rise on average. By comparing this average industry rise to the rise in reported earnings for a pyramidal gold firm, we have a measure for diversion. In other words, if the rise in gold prices increases profits in comparable firms by $\$ 100$, and we know that the pyramidal firm reports a rise of $\$ 90$, we can guess that $\$ 10$, on average, has been diverted away. Note that this is only a statistical measure of diversion, working on average over all firms, rather than being an accurate measure for every firm. The difference between reported and predicted performance for any given firm may be driven by numerous other idiosyncratic factors. ${ }^{15}$

The ability to observe shocks to fundamental earnings also allows us to track the flow of money.

\footnotetext{
15 Our test relies of the assumption that these factors are in fact idiosyncratic, i.e., that they cancel out when we aggregate. In Section IV.1, we discuss arguments for non-cancellation. For example, gold firms in pyramids may be partly diversified. In this case, we may systematically see such firms responding less than the average industry response to the shock, even in the absence of tunneling.
} 
Consider again the pyramid in Figure 1. Suppose a shock should raise the fundamental earnings of firm D. If money is being diverted at the margin from firm D to firm A (as tunneling implies), then we would expect A to respond to D's shock.

The theoretical analogues for these two measures (how much a firm responds to its own shock, and how much other firms in the pyramid respond to that shock) are $\frac{\partial E_{k}}{\partial F_{k}}$ and $\frac{\partial E_{j}}{\partial F_{k}}$. The predictions from our model tell us what tunneling implies. First, the diversion out of lower-down firms implies both that (i) pyramidal firms respond less than one for one to their shock $\left(\frac{\partial E_{k}}{\partial F_{k}}<1\right)$ and (ii) the under-response is greatest in lower-down firms $\left(\frac{\partial E_{k}}{\partial F_{k}}\right.$ declining in $\left.k\right)$. The tunneling of resources back into higher-up firms implies that (i) firms in a pyramid will respond to each other's shocks $\left(\frac{\partial E_{j}}{\partial F_{k}}>0\right)$; (ii) high-up firms will respond more to other firms' shocks $\left(\frac{\partial E_{j}}{\partial F_{k}}\right.$ decreasing in $\left.j\right)$; and (iii) firms will respond more to the shocks that affect low-down firms $\left(\frac{\partial E_{j}}{\partial F_{k}}\right.$ increasing in $\left.k\right)$.

The kind of shocks needed to implement these tests can be constructed readily. In our empirical work below, we will use mean industry movements as our shock. Beyond this, one could consider movements in commodity prices, movements in exchange rates, changes in energy cost and so on. ${ }^{16}$

To transform our test into regressions, we need to introduce some new notation. Let $p e r f_{k t I}$ be a level performance measure for firm $\mathrm{k}$ (which is in industry $\mathrm{I}$ ) at time $\mathrm{t}$, such as change in market value or profits in dollars. Associated with the level measure will be a return measure, $r_{k t I}$, and an asset measure, $A_{k t I}$, where $r_{k t I}=\frac{p e r f_{k t I}}{A_{k t I}}$. For example, if per $f_{k t I}$ were profits in dollars, $r_{k t I}$ could be profits divided by a measure of assets such as gross fixed assets.

With these measures in hand, we will need to compute the overall industry performance. Call this $r_{I t}$. We can estimate industry performance by using the returns of all the firms in the industry. We simply form the asset-weighted average of all the firms' returns: $\hat{r}_{I t}=\sum_{k} A_{k t I} r_{k t I} / \sum_{k} A_{k t I}$,

\footnotetext{
16 Bertrand and Mullainathan (2000) use these shocks to generate variation in fundamental earnings for US firms.
} 
where the sum is taken over all firms $\mathrm{k}$ in industry $\mathrm{I} .{ }^{17}$ Given the industry return, our prediction of each firm's performance will merely be its assets times the industry return: $p r e d_{k t I}=A_{k t I} * \hat{r}_{I t}$.

With this in hand, we can address the first set of questions. ${ }^{18}$ Let $p y r_{k}$ be a dummy variable for whether firm $k$ is in a pyramid or not. We need to merely estimate the regression:

$$
\operatorname{perf}_{k t}=a+b\left(\operatorname{pred}_{k t}\right)+c\left(\operatorname{pyr}_{k} * \operatorname{pred}_{k t}\right)+d\left(\text { controls }_{k t}\right)+\text { Firm }_{k}+\text { Time }_{t}
$$

where control $_{k t}$ are other variables that might affect firm performance (for example, age), Firm ${ }_{k}$ are firm fixed effects and Time $_{t}$ are time dummies. The coefficient $b$ on $\operatorname{pred}_{k t}$ indicates how sensitive firms are, in general, to industry performance. ${ }^{19}$ The interaction term pyr $_{k} *$ pred $_{k t}$ asks whether pyramidal firms are differentially sensitive to industry performance. If they are less sensitive, as skimming would predict, then $c$ should be negative. Moreover, because the regression is in performance levels, the magnitude of the effects is easy to interpret. If $b=1$, it means that the non-pyramidal firm responds 1 for 1 to each shock. If $c=-.1$, it means that the pyramidal firm is $10 \%$ less sensitive to the shock.

The first regression tests for reduced sensitivity $\left(\frac{\partial E_{k}}{\partial F_{k}}<1\right)$ of pyramidal firms relative to stand alones. We now turn to testing whether, among pyramidal firms, lower down ones show the least sensitivity $\left(\frac{\partial E_{k}}{\partial F_{k}}\right.$ declining in $\left.\mathrm{k}\right)$. Let position $_{k}$ be the position of firm $k$ so that a larger number represents a firm that is lower down. We then estimate the following regression for the sample of pyramidal firms only:

$$
\operatorname{perf}_{k t}=a+b\left(\text { pred }_{k t}\right)+c\left(\text { position }_{k} * \operatorname{pred}_{k t}\right)+d\left(\text { controls }_{k t}\right)+\text { Firm }_{k}+\text { Time }_{t}
$$

\footnotetext{
17 A mechanical correlation arises if we include a firm in estimating its industry's return and then use industry return to predict that firm's own return. To prevent this, we will actually exclude, for every firm, the firm itself in compute its industry return. In this sense $\hat{r}_{I t}$ should actually be indexed also by $k$, but we will drop this subscript for simplicity.

18 In what follows, we drop the industry index $I$ for ease of presentation.

19 It might appear puzzling that we used the word "shocks" in our general discussion, whereas our regressions use industry return and not change in industry return. The reason is that the regressions include firm fixed effects, which imply that our variation comes from within firm changes, and hence industry shocks.
} 
As before, the interaction term, position $_{k} * \operatorname{pred}_{k t}$, measures differential sensitivity. If lower down firms are less sensitive, we would expect $c$ to be negative.

We next test the flow of cash between firms in a pyramid. It would clearly be intractable to examine the sensitivity of every firm to every other firm's shock, as is suggested by $\frac{\partial E_{j}}{\partial F_{k}}$. Instead, we will look at how firms respond to the sum of the shocks to all other firms in the pyramid. For each firm $k$, we will define this as $\operatorname{opred}_{k t}=\sum_{j \neq k}$ pred $_{j t}$ where the sum is over all other firms in the group. We can then ask whether pyramidal firms are sensitive to the shocks affecting other firms:

$$
\operatorname{perf}_{k t}=a+b\left(\text { pred }_{k t}\right)+c\left(\operatorname{opred}_{k t}\right)+d\left(\text { control }_{k t}\right)+\text { Firm }_{k}+\text { Time }_{t}
$$

A positive coefficient on opred $_{k t}$ suggests that firms within a group are in fact sensitive to each other's shocks. It is worth noting that we control for the firm's own shock. This control means that we do not confuse an overlap of industry between firms in the same pyramid with flow of cash within that pyramid. A further prediction of tunneling is that higher up firms are the ones that are most sensitive to other firm's shock ( $\frac{\partial E_{k}}{\partial F_{j}}$ decreasing in $\mathrm{k}$ ). To test this, we simply include an interaction term between position and other firm's shock:

$$
\operatorname{perf}_{k t}=a+b\left(\text { pred }_{k t}\right)+c\left(\text { opred }_{k t}\right)+d\left(\text { position }_{k} * \operatorname{opred}_{k t}\right)+e\left(\text { controls }_{k t}\right)+\text { Firm }_{k}+\text { Time }_{t}
$$

If the prediction of tunneling were true, we would expect $d$ to be negative: a reduced sensitivity to group shocks for lower down firms.

Our final test asks whether firms are more sensitive to shocks that affect low down firms $\left(\frac{\partial E_{k}}{\partial F_{j}}\right.$ increasing in $\mathrm{j}$ ). We cannot test this by merely including an interaction term as for the last prediction. Instead we need to decompose the actual total shock. To do this, let $P$ be such that firms with position $_{k}>P$ can be thought of as low in the pyramid and firms with position $k \leq P$ 
can be thought of as high in the pyramid. For example, $P$ may be chosen so that we isolate the bottom and top half of the firms in a pyramid. We then define

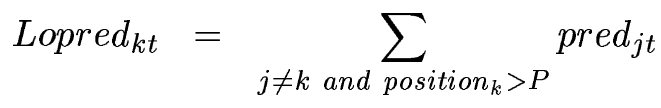

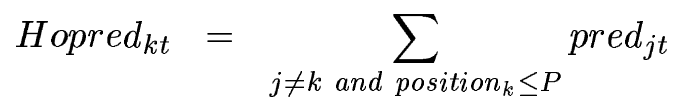

These measures are defined so that opred $_{k t}=$ Lopred $_{k t}+$ Hopred $_{k t}$. We can then estimate

$$
\operatorname{perf}_{k t}=a+b\left(\text { pred }_{k t}\right)+c_{L}\left(\text { Lopred }_{k t}\right)+c_{H}\left(\text { Hopred }_{k t}\right)+d\left(\text { controls }_{k t}\right)+\text { Firm }_{k}+\text { Time }_{t}
$$

If in fact firms are more sensitive to the shocks to low down firms, we would expect that $c_{L}>c_{H}$.

To summarize, these five regressions use the industry performance as a shock to test each of the theoretical predictions in the previous section. The data requirements for these regressions are modest. We need performance (accounting or market) information on a panel of firms. We need information on each firm's industry in order to compute the associated shock. We also need proxies for position in the pyramid, position $k$. The ideal would be a measure of the ultimate owner's cash flow rights, which we can use to label low down firms as ones in which the ultimate owner has little cash flow rights. As we will see below, one can use cruder but more readily available proxies. Data that allow us to compute these measures are all that are needed to perform our tests.

\section{Results from Indian Data}

\section{III.1 Data Source}

We illustrate our test using one such data set: the Prowess database, developed and maintained by the Centre for Monitoring Indian Economy (CMIE). Prowess is a publicly available database 
that includes annual report information for companies in India over the period 1989 to 1999 . This data provides much of the information needed: financial statement data, industry information, group affiliation for each firm and some corporate ownership data. We exclude state-owned and foreign-owned firms from our sample since these may not be comparable to the privately owned domestic firms that interest us. There are about 18500 firm-year observations in our sample, though sample sizes vary because of missing variables for some firms.

We rely on CMIE classification of firms into group and non-group firms, and of group firms by group affiliation. CMIE classification is based on a "continuous monitoring of company announcements and a qualitative understanding of the group-wise behavior of individual companies" (Prowess Users' Manual, v.2, p.4). Note also that CMIE classifies each company under a unique ownership group, based on the group the company is the most closely associated with. Conversations with local experts corroborate this classification; which group a firm belongs to is widely known. Like in many other countries, group firms in India are often linked together through the ownership of equity shares and often the ultimate controllers of the group are a family. Among the best-known business families in India are Tata, Bajaj, Birla, Oberoi and Mahindra. ${ }^{20}$ Group firms and non-group firms respectively account for about 7,500 and 11,000 of the observations in the full sample.

\section{III.2 Measurement of Pyramid Levels and Performance}

The ownership data from CMIE only allows us to construct imperfect proxies for position in the pyramid. CMIE provides information on equity holding patterns for about $60 \%$ of the firms in the database, reporting the shares of equity held by foreigners, directors, various financial institutions,

20 Piramal (1996) and Dutta (1997) provide descriptive accounts of groups in India. 
banks, various governmental bodies, the top fifty shareholders, corporate bodies, and others. ${ }^{21}$

Since this data cannot be used to form the exact ownership chains, like those in Figure 1, we will need to use proxies for the cash flow rights held by the ultimate owner.

Families typically control firms in which they have financial stakes by appointing family members or family friends to the board of directors and (very likely consequently) to the top managerial positions. There is a lot of evidence that India is no exception to that pattern. For example, the Financial Times Asia reports that "the boards of Indian companies...are invariably filled with family members and friends, whether or not they are qualified for the position" (Financial Times Asia Intelligence Wire, October 10, 1999). ${ }^{22}$ We, therefore, suggest that the equity stake of the directors may form a good proxy for the family's cash flow rights.

Another measure, equity held by "other shareholders", provides us with a measure of how much cash flow rights the family does not own. Other equity is defined as shares that are held neither by directors, nor banks, nor foreigners, not financial institutions, nor government bodies, nor corporate bodies, nor the top fifty other shareholders. It measure shares that are almost certainly held by outside shareholders. So, for example, a firm that has $25 \%$ equity held by outsiders will be ranked as higher up than one that has $70 \%$ equity held by outsiders. In the latter firm, the ultimate owner likely has no more than $30 \%$ holdings, while in the former he may have up to $75 \%$.

Formally, let $o_{i}$ be the level of other ownership in a firm and $r_{i}$ be the level of director ownership in that firm. If we assume that the ultimate owner gets all the cash flow arising from director ownership, then the ultimate owner's direct stake in a firm must be no less than the level of

\footnotetext{
21 The exact ownership categories reported by CMIE are: Foreigners, Insurance Companies, Life Insurance Corporation, General Insurance Corporation, Mutual Funds, Unit Trust of India, Financial Institutions (Industrial Financial Corporation of India, Industrial Development Bank of India, Industrial Credit and Investment Bank of India, Industrial Credit and Investment Corporation, Commercial Banks), Government Companies (Central Government Companies, State Government Companies), State Finance Corporation, Other Government Organizations, Corporate Bodies, Top Fifty Shareholders and Others.

22 The article actually goes on to say: "In such an environment, the promoter can operate to further his own interests even as he takes the other shareholders for a ride."
} 
director ownership: $d_{i} \geq r_{i}$. Recalling that the total cash flow rights $c_{i}$ of the ultimate owner are weakly greater than his direct stake $d_{i}$, we conclude that $c_{i} \geq r_{i}$, i.e., that director ownership lower bounds the ultimate owner's total cash flow rights. ${ }^{23}$ On the other hand, assuming that the "other" category does not include any ownership by firms held by the ultimate owner, it is easy to see that $c_{i} \leq 1-o_{i}$. In other words, the cash flow rights can at most be one minus what is held by the minority shareholders. Putting these together, we get that

$$
r_{i} \leq c_{i} \leq 1-o_{i}
$$

Thus, director ownership forms a lower bound for cash flow rights, while $1-o_{i}$, the non-minority ownership, forms an upper bound. ${ }^{24}$

Because we use within-group differences in director and other ownership levels to identify the direction and magnitude of money flows across firms in a business group, we exclude from the sample all groups where there is no difference between the maximum and the minimum level of director ownership or between the maximum and minimum level of other ownership. For such groups, we would, indeed, not be able to assess whether a given firm is high or low in its pyramid.

Both measures introduce error. This measurement error can create attenuation bias problems, biasing our estimates towards zero and raising standard errors. But, as we shall see, the bias is weak enough that we continue to find results. They do suggest that we may underestimate the extent of tunneling. Finally, the imperfect measurement provided by this CMIE can be viewed in two ways. On the one hand, it may make it a less than perfect place to apply our test. On the other hand, the CMIE data may be more representative of the typical data available to implement our test. While most countries do not keep detailed data on ownership between firms, many have

\footnotetext{
23 There may be some difference between ultimate owner's cash flow rights and our director's ownership measure if some of the directors are not part of the ultimate owners.

24 These two measures correlate negatively as would be expected, but they are only imperfectly correlated (about -.35 for group firms) suggesting that they are not redundant proxies. Also, besides measuring the absolute level of director and other equity holdings, we will also measure the relative level within the group of each one.
} 
readily available data of the kind provided by CMIE.

Our performance measures will be accounting ones. We focus on accounting measures over stock market measures for two main reasons. The first reason relates to data constraints. The CMIE data we possess does not allow one to easily compute annual return measures for a large set of firms. ${ }^{25}$ Moreover, the stock market data in India is extremely noisy. Only a small subset of the firms in our sample are traded on a regular basis and thus liquid enough to generate informative stock price data. This thinness makes it hard for us to generate informative industry shock measures. The second reason for focusing on accounting data is that they provide a richer source of information for the test we wish to perform here. More specifically, accounting returns have the advantage that they can be decomposed into more detailed components. For example, we can examine whether the operating profits of high-up firms rise in response to shocks elsewhere in the group, which may be indicative of the use transfer pricing to tunnel resources.

Stock prices would, however, be very helpful to incorporate. To this end, we will exploit the information we have on market capitalization. We will use this information to compute q ratios. We will then study the relationship between $q$ and the extent of diversion.

Our specific performance measure, $\operatorname{per} f_{k t I}$, will be profits before depreciation, interest and tax. Our asset measure, Assets $s_{k t I}$, will be total assets of the firm. Each firm's industry comes from CMIE's classification of firms into industries. There are 134 different 4-digit industries in our sample and appendix Table 1A lists them. As can be seen from this table, these 4-digit classification corresponds roughly to the 4-digit SIC code.

\footnotetext{
25 While CMIE possesses such data, their interface only allows extraction on a firm by firm basis, making the task extremely time intensive given the thousands of firms that we have. We can get market capitalization data from the balance sheet but without dividend data these cannot be made into a return measure.
} 


\section{III.3 Summary Statistics}

Table 1 reports summary statistics for the full sample and for group and non-group firms separately. All nominal variables in the sample are deflated using the Consumer Price Index series from the International Financial Statistics of the International Monetary Fund $(1995=100)$. In this table, and throughout the remainder of the paper, the designation "stand alone" is equivalent to "non-group."

The average group firm in the sample belongs to a group that contains about 15 firms. There are, however, a lot of small groups consisting of two of three firms. Because such small groups may not actually correspond to the basic theoretical concept of a pyramid, we will report most of the results below for both the entire set of groups and for the subset of groups that have more than five firms. ${ }^{26}$

Group firms are, on average, 12 years older than non-group firms. The typical group firm was created in 1967, while the typical stand alone firm's year of incorporation is 1979. More importantly, group firms are, on average, much larger than stand alone firms. The average group firm has total assets of Rs. 253 crore, while the average stand alone firms has total assets of Rs. 52 crore. Stand alone firms also have lower levels of sales and lower levels of profits. In the results below where we compare group and non-group firms' sensitivity to own industry shock, we will account for this difference in size and age. The average level of director ownership among group firms is $7.5 \%$. The average level of ownership by other shareholders is $27.5 \%$. The gap in director ownership between the top and bottom of a group (i.e., the gap between the firm with the highest level of director

\footnotetext{
26 We have learned more about the nature of these smaller groups through various conversations with CMIE employees. Some ownership groups have several companies of smaller size that are setup for some taxation or retail business purpose. Because not all of these companies may be listed, it is much more difficult for CMIE to get access to their Annual Reports. CMIE also tracks subsidiary companies with small turnovers but does not include them in the database we use in this paper.
} 
ownership and the firm with the lowest level of director ownership) is $15 \%$ on average. The average gap in other ownership is $33 \%$.

\section{III.4 Sensitivity to Own Shock}

We begin by testing in Table 2 whether group firms are less sensitive to shocks than stand alones. To this end, we estimate equation 1:

$$
\operatorname{perf}_{k t}=a+b\left(\text { pred }_{k t}\right)+c\left(\text { pyr }_{k} * \operatorname{pred}_{k t}\right)+d\left(\text { controls }_{k t}\right)+\text { Firm }_{k}+\text { Time }_{t}
$$

Recall that $c$ will be the key coefficient of interest.

Column 1 displays the result for our entire sample. A one rupee shock leads to about a one rupee increase in earnings for a stand alone firm. For a group firm, it leads to .3 rupee smaller increase, or only a .7 rupee increase. Column 2 shows that this result is unchanged when we exclude the groups of less than five firms from our sample. These results would suggest that $30 \%$ of all the money placed into a group firm is dissipated somehow.

We showed in Table 1 that stand alone firms are smaller on average. If size affects responsiveness to shocks, one might then be concerned that we are confounding the effects of size and ownership structure. In the next two columns, we establish that our earlier finding appears robust to accounting for size differences. We allow in columns 3 (all groups) and 4 (large groups only) for an additional interaction term between the logarithm of total assets and industry shocks. ${ }^{27}$ The results are unaffected. In all specifications, there is about a .3 rupee lower earning response in group firms relative to stand alone firms.

In Table 1, we also established that group firms are, on average, older than stand alone firms. In columns 5 (all groups) and 6 (large groups only), we directly allow for firms of different age to

\footnotetext{
27 Obviously, we also directly control for the logarithm of total assets.
} 
respond differently to shocks to their industry. We do find that firms incorporated more recently are indeed more responsive to their industry shock. The main finding of the previous columns is, however, roughly unaffected. The coefficient on "Own Shock*Group" is now .26 and is not statistically different from the estimated coefficient in columns 1 to 4 . Finally, in columns 7 and 8 , we simultaneously allow for interactions of "Own Shock" with firm size and firm's year of incorporation. Again, the results are unchanged.

Group firms' profitability thus seems to be less tied to their industry shock than is the profitability of non-group firms. While this result is interesting and consistent with the idea that business groups are tunneling money, we do not wish to push it too far a comparison of group and stand alone firms. One major concern to us is that group firms might be more diversified than non-group firms. Differential diversification could then in large part explain the differential sensitivity to "main" industry shock. We return to this issue in Section IV.1.

We now turn to evidence for tunneling that no longer relies on comparing group to stand alone firms, but instead focuses on differences within group firms. In Table 3, we test whether lower down firms are less sensitive to their shock. We estimate equation 2:

$$
\operatorname{perf}_{k t}=a+b\left(\text { pred }_{k t}\right)+c\left(\text { position }_{k} * \operatorname{pred}_{k t}\right)+d\left(\text { controls }_{k t}\right)+\text { Firm }_{k}+\text { Time }_{t}
$$

for the sample of pyramidal firms. Again we expect $c$ to be negative.

Panel A considers director's equity as our proxy for the position of firms in their group. Column 1 shows that group firms that have more director equity are more sensitive to their own industry shock. Each 1 percentage point increase in director equity increases the sensitivity to a one rupee industry shock by .03 rupee. Column 3 establishes that these findings hold when we concentrate on the subsample of groups of at least 5 firms. In fact, the effect of director ownership appears even stronger among the larger groups (.04 instead of .03). Recall that among group firms, the average 
difference in director ownership between the firm with greatest director ownership and the firm with the least director ownership was 15.9. Thus, the typical top firm is .45 rupees more sensitive than the bottom firm for each rupee of industry shock. This hints that the top group firms might be as sensitive as a stand alone firms to the marginal rupee. The magnitude of these effects is striking. They suggest that ownership plays a large role in the extent of the sensitivity.

One might worry that the findings in columns 1 and 3 solely capture some aspects of director ownership that are unrelated to group ownership. We address this worry in column 5 where we reproduce the same regressions as above but focus on the sample of stand alone firms. We find that director ownership also increases the responsiveness to shocks for stand alone firms. However, the effect is quantitatively much smaller, only a tenth of the size for stand alone firms (.004 instead of .03 or .04 for group firms).

In columns 2,4 , and 6 , we allow for the effect of own industry shock to differ by firm size and firm age. These additional controls do not modify the estimated coefficient on "Own Shock*Director Ownerhip" in either of the two group firm samples. These additional controls, however, lead to an increase in the coefficient on "Own Shock*Director Ownership" in the sample of stand alone firms (.019 instead of .004). Because standard errors are relatively small, we can still reject that the effect of director ownership on industry group sensitivity is the same between group firms and stand alone firms. More director equity increases the responsiveness of a firm to its own industry shock and this effect is significantly larger among group firms.

In Panel B, we consider our second proxy for the position of a group firm within its business group: other ownership. As predicted, we find that the sensitivity a group firm to its own industry shock decreases with its level of other ownership. This result holds whether we look at all groups (column 1) or restrict ourselves to the subsample of groups of more than 5 firms (column 3 ). A one 
percentage point increase in other ownership decreases the responsiveness of a group firm to a one rupee shock by about .01 rupee. Given that the average spread between top and bottom group firms in other ownership is 33.31, the implied magnitude of effect is the same as in Panel A. Among stand alone firms (column 5), the effect of other ownership is of the opposite sign and economically small. Finally, note also that the coefficient on "Own Shock*Other Ownership" is roughly unaffected by the inclusion of controls for firm age and firm size interacted with own industry shock (columns 2 , 4 and 6$)$.

In summary, the results in Table 3 are consistent with the idea that less resources are tunneled out of the group firms where the promoting family has higher equity stakes and where there are less minority shareholders to expropriate. The magnitude of the effects are also large. Firms high up in our measures of pyramidal level show roughly the same sensitivities to their own industry shocks as stand alone firms.

\section{III.5 The Effect of Group Shocks}

We now turn to the propagation of shocks to other firms, a crucial component of our test. Without this evidence, it is possible that group firms are merely mismanaged. In such a case, the reduced sensitivity would not represent diversion of resources elsewhere, but merely dissipation of resources by inefficient operation. In the next tables, we therefore examine how firms respond to shocks to other firms in their groups. The first column of Table 4 estimates equation 3:

$$
\operatorname{perf}_{k t}=a+b\left(\operatorname{pred}_{k t}\right)+c\left(\text { opred }_{k t}\right)+d\left(\text { controls }_{k t}\right)+\text { Firm }_{k}+\text { Time }_{t}
$$

We ask whether $c>0$.

The coefficient on "Own Shock" is in line with what we found previously: on average, the earnings of group firms respond only by .73 rupee for a one rupee shock to their industry. More 
importantly, we also find that a typical group firm reacts to shocks to the other firms in its group. The coefficient on "Group Shock" of .011 suggests that for each rupee earned by the group, other firms in the group receive on average .011 rupee. The results stay unchanged when we look at large groups. In assessing the magnitude of this coefficient, recall that it averages a potential tunneling effect in two ways. First, it cumulates shocks to bottom firms in the group (where we would expect the money to come from) as well as to top firms in the group. Second, it includes the sensitivity of all firms, not only the top firms in the group (where we would expect the money to go to).

In columns 2 to 5 , we ask whether the source of the shock matters, i.e. whether shocks that affect low down firms are redistributed more. We thus estimate equation 5:

$$
\operatorname{perf}_{k t}=a+b\left(\text { pred }_{k t}\right)+c_{L}\left(\text { Lopred }_{k t}\right)+c_{H}\left(\text { Hopred }_{k t}\right)+d\left(\text { controls }_{k t}\right)+\text { Firm }_{k}+\text { Time }_{t}
$$

In column 2, we split firms into low and high as a function of median director's equity in each group. The results show greater sensitivity to shocks affected firms lower in the pyramid. A 1 rupee shock to firms below group median in terms of director ownership increases the average group firm's earnings by 0.02 rupee. By contrast, the average group firm's earnings do not respond to industry shocks to the higher-up firms. Column 3 instead contrast shocks to firms below and above the 66 th percentile of director equity in their group. We therefore now isolate a smaller group of firms in the "top group" and allow for resources to be equally skimmed from a larger number of firms lower down in the group. The results are very similar.

In columns 4 and 5, we repeat the same exercise but focus on responsiveness to shocks higher up and lower down in the group as measured by minority ownership. In column 4, we break down the overall group shock into two sub-shocks: shock to group firms with above median "other equity" (i.e., bottom firms) and shock to group firms with below median "other equity" (i.e., top firms firms). In that case, we find that the average group firm is equally sensitive to the two sub- 
shocks. In column 5, we isolate a larger set of firms at the bottom by using the 33rd percentile of "other equity" as the breaking point. The results indicate that few to no resources seem to be transferred from the higher-up firms towards other group firms: the coefficient on the higher-up shock is basically zero. The coefficient on the lower-down shock is .02 .

\section{III.6 Does Money Go to the Top?}

The results in Table 4 are consistent with the idea that an average group firm financially benefits more from the earnings shocks happening at the bottom of its group than from the earnings shocks happening at the top of its group. Hence, more resources seem to be tunneled out of lower down firms. The next natural step is to disaggregate in the other direction and ask where these resources are tunneled to. Are higher-up group firms more sensitive to the group shock than lower-down firms? To this end, we estimate equation 4:

$$
\operatorname{perf}_{k t}=a+b\left(\operatorname{pred}_{k t}\right)+c\left(\operatorname{opred}_{k t}\right)+d\left(\text { position }_{k} * \operatorname{opred}_{k t}\right)+e\left(\text { control }_{k t}\right)+\text { Firm }_{k}+\text { Time }_{t}
$$

We ask whether $d<0$.

In Table 5, we rank firms based on their within-group level of director equity and construct four different subsamples: firms with below the 66th percentile of director equity in their group, firms with above the 66 th percentile of director equity in their group, firms with strictly less than the highest level of director equity in their group and firms with the highest level of director equity in their group. We compare sensitivity to group shocks and sub-group shocks for firms in these four different levels. Each regression includes, in addition to the variables reported in the table, the logarithm of total assets, year fixed effects and firm fixed effects. The dependent variable in the all regressions is still profit before depreciation, interest and taxes.

When we contrast firms above and below 66th percentile in director equity (columns 1 and 2), 
we find no statistically significant differences in their sensitivity to group shocks. In fact, the point estimate on "Group Shock" is higher for the lower-down firms (.013 v.s. .010). ${ }^{28}$ The top $\frac{1}{3}$ firms are thus not more sensitive to the group shock. Recall, however, that we predicted that it is the top-most firm that should show the greatest sensitivity. In columns 3 to 8 , therefore, we contrast the sensitivity of the top-most firm in the pyramid to that of the lower-down firms. ${ }^{29}$ With this split of the data, the theoretically expected patterns start emerging. Firms at the very top gain about .02 rupee for every one rupee shock to their group (column 6). Firms under the very top gain only .012 rupee for the same one rupee shock (column 3). Because standard errors are rather large in column 6 , these two estimates are however not statistically different. Interestingly, when we break down the overall group shock into two sub-shocks, the results become even more suggestive. We find that top firms gain between .032 and .034 rupee for every one rupee shock to group firms either below the 66 th percentile in terms of director equity or above the $33 \mathrm{rd}$ percentile in terms of minority ownership. ${ }^{30}$ Firms strictly under the top only gain between .015 and .017 rupee on average for the same sub-shocks. To summarize, these results suggest that the top-most firms seem to benefit most from shocks to the group. Moreover, they benefit most of all from shocks to lower down firms.

\section{Extensions}

\footnotetext{
28 Similar results follow if we use median cutoffs.

29 When firms "tie" in their level of director's ownership we call both of them the top firm. In this sense, more than one firm may be at the top.

30 Recall the theoretical discussion in Section II.1, which predicted when money should go to the top. If we take these final results seriously, our evidence suggests that in fact a model where there is no increasing marginal cost of diverting money fits the data best. But these results should be taken cautiously because the standard errors are larger than in previous tables.
} 


\section{IV.1 Alternative Explanations}

The results so far have been consistent with tunneling. But could they be explained by something else? There are three prominent alternative explanations that we can see and ought to discuss. First, one might worry that our results merely arise from the fact that group companies own shares in each other. The apparent sensitivities of group firms to each other's performance would then mechanically arise through the dividend earnings from the shares held in each other. Note to start that some of our findings are hard to reconcile with that interpretation. Because of the dilution effect, firms at the top of their group should be less sensitive to the group shocks than firms in the middle of their group. We however investigated the validity of this alternative explanation in more details. ${ }^{31}$ We studied the source of earnings sensitivity to group shocks and found little or no effect on dividend earnings.

Second, we may be mismeasuring a firm's industry. What we call a tea firm may also have other subdivisions. This mismeasurement would lead firms to appear less sensitive to "their" industry shock. As noted earlier, for diversification of this type to explain our result, several other facts would need to be true. First, group firms would need to be more diversified than stand alone firms are. Intuitively though, the opposite would seem more likely since groups can diversify between firms, while stand alone firms, if wanting to diversify, must do so within one shell. It would also need to be the case that top firms are, for some reason, less diversified than bottom firms are.

To address concerns about industry mismeasurement, we turn to detailed product data from CMIE. CMIE reports the set of products produced by each company. We analyze these data at two levels of aggregation. One level of aggregation, which we refer to as "12 digit" following CMIE's classification, is extremely detailed. For example, this level differentiates chili powder from chili puree. It contains over 10,000 product names. The other level of aggregation, which we refer to

\footnotetext{
31 These results are not reported here but are available from the authors upon request.
} 
as "2 digit", is less detailed. It includes categories such as animal products, agricultural products, base metals and so on. There are 22 such products. ${ }^{32}$ Studying these data carefully, we found that the primary product actually accounts for quite a large fraction of sales. Even at the 12 digit level, the largest product accounts for $80 \%$ of sales in the median firm. At the 2 digit level, the largest product accounts for $93 \%$ of sales in the median firm. These numbers suggest very little diversification and, thereby, lessens the chance that diversification might be driving our results.

In Table 6, we further investigate the hypothesis that diversification may differ between group and stand alone firms as well as by position in the group. At both the 2 and 12 digit level, we compute both Herfindahl and product count measures of diversification. ${ }^{33}$ The first two columns contrast group and stand alone firms. For all measures of diversification, a simple mean comparison shows that group firms appear to be more diversified than stand alones. At the two digit level, for example, they have .54 more products $(2.11-1.58)$. Moreover, these differences are statistically significant. But as the regression adjusted results show, controlling for firm characteristics (firm size and primary industry fixed effects) and years fixed effects completely removes these differences. Not only are they no longer statistically significant, there is no longer a consistent sign pattern. While the point estimate for the 2 digit product count measure shows that group firms are more diversified, the other three measures actually show less diversification in groups. ${ }^{34}$ Because we control for these variables in our tunneling tests, the regression adjusted comparisons are the relevant ones.

In the next four columns we examine the relationship between position in group and diversification. Recall that for diversification to explain our results, lower down firms need to be more

\footnotetext{
32 The CMIE data is structured in such a way that in between levels of aggregation are extremely hard to construct.

33 Herfindahl measures are the sum of the square of each product's share of output for all products. A higher Herfindahl, therefore, actually denotes lower diversification. Product count measures merely count the number of products.

34 Size differences are the driving factor in the regression adjustment. As we saw in Table 1, group firms are bigger and bigger firms are typically more diversified.
} 
diversified (hence their reduced sensitivity to their "industry" shock). The raw differences show no significant negative relationship between diversification and higher up position, whatever measure of diversification we use and whether we measure position in group using director equity or other ownership. If anything, we find a little evidence that lower down firms might in fact be less diversified. When we regression adjust these estimates, there is no consistent pattern left. To summarize, Table 6 shows little support for the idea that diversification differences are driving our results. ${ }^{35}$

Finally, one might question our results by arguing that they arise from optimal insurance between group firms. In countries such as India where capital markets are still nascent, groups may provide a valuable source insurance for their members (Khanna and Palepu 2000). During lean times in an industry, a group firm can provide financing or cash to other firms in its group, financing that stand alone firms may not have access to. Such informal insurance mechanisms between group members could produce some empirical patterns that might appear like tunneling. For example, a group firm could be less sensitive to its own industry shock because of the insurance it receives from other group firms. A group firm's performance could also be positively affected by shocks to the rest of its group if it provides insurance to other firms in the group.

While this explanation could explain some of our results, it is not clear at all why insurance should follow the line of ownership. In other words, if reduced sensitivity to own industry shocks represents insurance, why do group firms with high director ownership systematically show less "insurance"? Also, why does "insurance" flow in one direction, with firms at the top being sensitive to shocks to the firms below them, but not vice versa? To accommodate these findings, one would have to add one important assumption to the insurance story. Suppose firms or industries differ in the amount of cash they generate. The cash cows that generate large amounts of cash would be

\footnotetext{
35 These findings aside, diversification also would not be able to explain our finding below on operating and non-operating profits. As we will see shortly, the differential sensitivity seems to come from non-operating profits only and not operating profits.
} 
the natural providers of insurance within a group, while the cash-strapped firms would more likely be the receivers of insurance. Cash-strapped group firms would then be less sensitive to their own shock than their stand alone counterparts. Moreover, cash-rich firms would often be sensitive to the industry shocks of the cash-strapped firms in their group, but not vice versa. Thus, for an insurance story to explain our results, it would need to be the case that position in the pyramid proxies for cash richness. Higher-up firms in the pyramid are in more cash-rich industries and, hence, provide more insurance. Lower-down firms in the pyramid are in the less cash-rich industries and, hence, receive more insurance.

We test for this hypothesis in two ways. We begin by simply comparing the cash richness of industries by pyramidal level. We measure the cash richness of an industry as the industry average ratio of profits before depreciation, interest and taxes over assets. Firms low in the pyramid, those with director equity below median, average $.155(.054)$ on this measure. Firms high in the pyramid, those with director equity above median, average .154(.038) on this measure. Hence, firms higher up in business groups do not seem to systematically belong to industries that are relatively more cash-rich, as would be required by the insurance story.

Second, in Table 7, we formally investigate what happens when we control for industry cash richness in Table 3. Can differences in cash richness explain away the the differential sensitivity to own shock by pyramidal level found in Table 3 ? Column 1 of this table replicates column 1 of Table 3 but includes industry cash richness of the firm interacted with own shock. We find that this new interaction term does not affect the coefficient on "Own Shock*Director's Equity". The coefficient stays .025. Bottom firms continue to be the least sensitive to their own shock even after controlling for the effect of cash richness on sensitivity to own shock.

A directly related argument has to do with loans to and from group firms. Perhaps group firms 
provide loans to each other with "flexible" interest payments. This flexibility would then appear to generate some of the patterns we have observed in the data. To deal with this concern, we examine the effect of group lending on our results. In columns 2-4 in Table 7, we add to our basic regression in Table 3 an interaction term between various measures of lending level within a group and "Own Shock". In column 2, we use total lending in the group as our measure, that is, total loans from group firms to all firms in the group divided by total assets of all group firms. We do find here that total group lending reduces the sensitivity of group firms to their own industry shock. Firms in groups that lend more show a lower sensitivity to their own shock. But controlling for this effect does not affect the coefficient of interest, "Own Shock*Director's Equity." In column 3, we use the ratio of the loans received by the firm from its group over the firm's assets as an alternative measure of group lending. As before, this additional interaction term does not affect the "Own Shock*Director's Equity" coefficient. Finally, in column 4, we find that a firm's lending to other group firms reduces its sensitivity to its own shock, but again does not affect the coefficient we care

about. In summary, firms in groups that lend more do seem to display lower sensitivities to their own industry shock, but this effect does not drive our results.

As a whole, the findings in Table 7 cut against the optimal insurance story. Our attempts to account for insurance in our empirical tests have left our primary results unchanged. More broadly, we are unable to find supporting evidence for any of the prominent alternative explanations of our findings.

\section{IV.2 An Accounting Decomposition of the Effects}

If business groups in India are indeed tunneling resources, as the evidence we have built so far strongly suggests, how are they doing it? One way to address this question is by digging a little 
deeper into the details of the balance sheet.

We do this in Table 8, where we replicate the previous analysis but replace our standard profit measure with other balance sheet items. More formally, we decompose profits into two components:

$$
\text { Profits }=\text { Operating Profits }+ \text { Non-Operating Profits }
$$

Operating profits are defined as sales minus total raw material expenses minus energy expenses minus wages and salaries. ${ }^{36}$ Non-operating profits are the "residual." They include such diverse items as write-offs for bad debts, interest income, amortization, extraordinary items as well as unspecified items. In short, everything is included that may affect profits other than through the channels specified in operating profits.

Panel A compares the sensitivity of group and stand alone firms to their own shock for these two measures (as in Table 2). Each entry in this panel is the coefficient on "Own Shock" from a separate regression. We see in the first row that group firms' operating profits are, if anything, more sensitive to their own industry shock. It is on non-operating profits that they are far less sensitive to the shock. In other words, it appears that non-operating profits fall when there is a positive shock to a firm's industry. While we also observe a moderate fall for stand alone firms, the fall is much larger for group firms.

In Panel B, we examine the differential sensitivity to own industry shock by level in group (as in Table 3). For simplicity, we only report in this table the coefficient on "Own Shock*Director Equity". Each entry in this panel belongs to a separate regression. Also included in that regression are the logarithm of total assets, firm fixed effects, year fixed effects, and the direct effect of "Own Shock." We report in the second column the equivalent regressions for stand alone firms as a benchmark. The first row shows that there is little evidence of tunneling in operating profits.

\footnotetext{
36 Total raw material expenses include raw material expenses, stores and spares, packaging expenses and purchase of finished goods for resale.
} 
While group firms' sensitivity does rise with their director equity, stand alone firms show a nearly equivalent rise. The difference is only about .004. In the second row, however, we see a much greater effect on non-operating profits. The difference between group and stand alone firms is around .017, or four times the difference on operating profits.

In Panel C, we examine how each of the two profit measures respond to group shock (as in Table 5). These results complement those of Panels A and B since they tell us about the mechanisms for tunneling money into a firm. Each entry represents the coefficient on "Group Shock" from a separate regression which includes year and firm fixed effects, logarithm of total assets and own shock. We find a pattern very similar to that in Panels A and B. Much of the sensitivity of top firms to the group shock occurs on non-operating profits. (On operating profits, in fact, they are slightly less sensitive).

Hence, according to our findings in Table 8, the tunneling of money both into and out firms in India occurs through non-operating profits. ${ }^{37}$ This implies that transfer pricing (which would affect operating profits) is not an important source of tunneling in India. Moreover, it suggests that non-operating profits may be a force that moves in the opposite direction of operating profits and serves to dampen final earnings. In unreported regressions, we examined this by simply regressing a firm's non-operating profits on its operating profits, while controlling for size, year dummies and firm fixed effects. As expected, we found a strong negative coefficient. When we interacted operating profits in this regression with a variety of variables, we found results quite similar to our tunneling findings. Group firms showed a much more negative relationship between operating and non-operating profits. Also, amongst group firms, low down ones showed the most negative relationship. This evidence reinforces the view that the manipulation of non-operating profits

\footnotetext{
37 We have attempted further decomposition of non-operating profits and found no consistent pattern. No one sub component of non-operating profits is systematically more important. This may be because different firms tunnel in different ways.
} 
appear is a primary means of removing cash from and placing cash into firms in India.

\section{IV.3 Market Valuation}

Given our findings so far, it is natural to ask whether stock prices reflect the extent of this tunneling. Answering this would serve as a consistency check on our findings but is also an interesting question in its own right. Is the market able to look through the accounting manipulations and discern that something "fishy" is going on? Does the market penalize those firms that show the greatest evidence of tunneling? These questions are also interesting because our initial motivation was the expropriation of shareholders. While the noisiness of stock returns data in India prevent us from directly using them as performance measures, examining how firm valuation relates to amount of tunneling provides a good compromise.

To address this issue, we compute for each firm an average q ratio. We do this by first regressing standard firm level q ratios (market valuation over total assets) on $\log$ (total assets), year fixed effects and industry fixed effects. The residual from this regression is the variable we call "Firm Q". Our q measure is, therefore, the market discount for the firm relative to other firms in its industry, size class and year. We also compute an average $\mathrm{q}$ ratio for each group. To do this, we estimate a similar regression at the firm level but include group fixed effects instead of firm fixed effects. The group fixed effects from these regressions define the variable we call "Group Q". Finally, we form a "Relative Q" measure for each firm, which equals its own q minus its group q. Relative q thus measures how well a firm performs relative to other firms in the group.

In Table 9, we examine how these new variables influence the sensitivity of a firm to its own shock and to the group shock. In column 1, we show that firms with higher q are more sensitive to both their own shock and to the group shock. Under the tunneling interpretation, this suggests 
that firms which have more resources transferred to them and less resources taken away from them have higher q ratios. In column 2 , we see the same pattern for relative q. In column 3 , we see that the groups with the highest $\mathrm{q}$ are those in which firms show higher sensitivity to their own shock, or those in which firm have less resources taken away from them. The coefficient on group shock interacted with "Group Q" is positive but insignificant. In column 4, we include interactions of the shock measures with both "Own Q" and "Group Q". The results are qualitatively similar to those in columns 1 and 3 .

The findings in this section therefore suggest that the stock market does recognize and value tunneling. Firms that have more resources tunneled to them are valued more by the market. Firms that have fewer resources tunneled from them are also valued more. Finally, groups that tunnel less resources are valued more.

\section{Conclusion}

We have attempted to develop a fairly general empirical methodology for exploring the extent of tunneling activity in pyramids. By examining how various firms respond to external shocks to their performance, we can trace out how much of the marginal dollar is being diverted. By examining which firms within a pyramid respond to other firms' shocks, we can trace where this marginal dollar is being diverted. When we applied this methodology to Indian data, we found considerable diversion. We also found that this diversion followed the lines of ownership, flowing from firms near the bottom of the pyramid to firms near the top of the pyramid. We were also able to discern that much of this diversion occurred on non-operating components of profits. These results suggest that the methodology may be usefully applied to many other countries. 


\section{Bibliography}

Bebchuk, L, R. Kraakman, and G. Triantis, "Stock Pyramids, Cross-Ownership, and Dual Class Equity: The Mechanisms and Agency Costs of Separating Control from Cash Flow Rights," in Concentrated Corporate Ownership, A National Bureau of Economic Research Conference Report, R. Morck, editor (Chicago, IL: University of Chicago, 2000).

Berle, A. and Means, G., The Modern Corporation and Private Property (New York, NY: MacMillan, 1934).

Bertrand, M. and S. Mullainathan, "Are CEOs Rewarded for Luck? The Ones Without Principals Are," Quarterly Journal of Economics, forthcoming.

Bianchi, M., M. Bianco, and L. Enriques, "Pyramidal Groups and the Separation Between Ownership and Control in Italy," mimeo, Bank of Italy, 1999.

Blanchard, O., F. Lopez-de-Silanes, and A. Shleifer, "What Do Firms Do with Cash Windfalls?" Journal of Financial Economics XXXVI (1994), 337-60.

Claessens, S., S. Djankov, and L. Lang, "The Separation of Ownership and Control in East Asian Countries," mimeo, World Bank, 2000.

Claessens, S., S. Djankov, J. Fan, and L. Lang, "Expropriation of Minority Shareholders: Evidence from East Asia," Policy Research Paper 2088, World Bank, 1999.

Dutta, S., Family Business in India (New Delhi: Response Books, Sage Publications), 1997.

Hoshi, T., A. Kashyap, D. Scharfstein, "Corporate Structure, Liquidity, and Investment: Evidence from Japanese Industrial Groups," Quarterly Journal of Economics, CVI (1991), 33-60.

Jensen, M., W. Meckling, "Theory of the Firm: Managerial Behavior, Agency Costs, and Ownership Structure," Journal of Financial Economics, III (1976), 305-360.

Johnson, S., P. Boone, A. Breach, and E. Friedman, "Corporate Governance in the Asian Financial Crisis," Journal of Financial Economics, (2000) forthcoming.

Johnson, S., R. La Porta, F. Lopez-de-Silanes, and A. Shleifer, "Tunneling," American Economic Review Papers and Proceedings, XC (2000), 22-27.

Khanna, T. and K. Palepu, "Is Group Membership Profitable in Emerging Markets? An Analysis of Diversified Indian Business Groups," Journal of Finance, LV (2000), 867-91.

Lamont, O., "Capital Flows and Investment: Evidence from the Internal Capital Markets," Journal of Finance, LII (1997), 83-109.

La Porta, R., F. Lopez-de-Silanes, A. Shleifer and R. Vishny, "Corporate Ownership around the World," Journal of Political Economy, LIV (1999), 471-518.

Leff, N., "Industrial Organization and Entrepreneurship in Developing Countries: The Economics Groups," Economics Development and Cultural Change, XXVI (197), 661-75.

Nenova, T., "The Value of a Corporate Vote and Private Benefits: Cross-Country Analysis," mimeo, Department of Economics, Harvard University, 1999.

Piramal G., Business Maharajas (Bombay: Viking Press, 1996). 
Shleifer, A. and D. Wolfenzon, "Investor Protection and Equity Markets," mimeo, Department of Economics, Harvard University, 2000.

Wolfenzon, D., "A Theory of Pyramidal Ownership," mimeo, Department of Economics, Harvard University, 1999.

Zingales, L, "What Determines the Value of Corporate Votes?" Quarterly Journal of Economics, CX (1995), 1047-73. 


\begin{tabular}{|c|c|c|c|}
\hline Sample: & All & Groups & Stand-Alones \\
\hline Total Assets & $\begin{array}{c}131.80 \\
(525.91)\end{array}$ & $\begin{array}{l}252.76 \\
(741.6)\end{array}$ & $\begin{array}{c}49.69 \\
(272.66)\end{array}$ \\
\hline Total Sales & $\begin{array}{c}94.39 \\
(305.66)\end{array}$ & $\begin{array}{c}188.16 \\
(459.77)\end{array}$ & $\begin{array}{c}30.73 \\
(57.84)\end{array}$ \\
\hline Net Profit & $\begin{array}{c}4.71 \\
(29.76)\end{array}$ & $\begin{array}{c}9.72 \\
(45.47)\end{array}$ & $\begin{array}{c}1.31 \\
(7.44)\end{array}$ \\
\hline $\begin{array}{l}\text { Profit Before Depreciation } \\
\text { Interest and Taxes }\end{array}$ & $\begin{array}{c}16.84 \\
(63.84)\end{array}$ & $\begin{array}{c}32.90 \\
(90.99)\end{array}$ & $\begin{array}{c}5.94 \\
(30.48)\end{array}$ \\
\hline Ratio of PBDIT to Total Assets & $\begin{array}{l}.126 \\
(.128)\end{array}$ & $\begin{array}{l}.142 \\
(.115)\end{array}$ & $\begin{array}{l}.115 \\
(.134)\end{array}$ \\
\hline Ratio of Operating Profit to Total Assets & $\begin{array}{l}.284 \\
(.285)\end{array}$ & $\begin{array}{l}.328 \\
(.312)\end{array}$ & $\begin{array}{l}.254 \\
(.261)\end{array}$ \\
\hline Ratio of Non-Operating Profit to Total Assets & $\begin{array}{l}-.157 \\
(.259)\end{array}$ & $\begin{array}{l}-.186 \\
(.288)\end{array}$ & $\begin{array}{l}-.138 \\
(.235)\end{array}$ \\
\hline q Ratio & $\begin{array}{l}.537 \\
(.818)\end{array}$ & $\begin{array}{l}.645 \\
(.916)\end{array}$ & $\begin{array}{l}.447 \\
(.714)\end{array}$ \\
\hline Year of Incorporation & $\begin{array}{l}1974.55 \\
(20.03)\end{array}$ & $\begin{array}{l}1967.51 \\
(22.89)\end{array}$ & $\begin{array}{c}1979.33 \\
(16.18)\end{array}$ \\
\hline Director Ownership & $\begin{array}{l}16.70 \\
(18.33)\end{array}$ & $\begin{array}{c}7.45 \\
(13.05)\end{array}$ & $\begin{array}{c}22.99 \\
(18.72)\end{array}$ \\
\hline Other Ownership & $\begin{array}{c}29.90 \\
(17.39)\end{array}$ & $\begin{array}{c}27.57 \\
(16.06)\end{array}$ & $\begin{array}{c}31.48 \\
(18.07)\end{array}$ \\
\hline Director Ownership Spread & - & $\begin{array}{c}15.19 \\
(14.88)\end{array}$ & - \\
\hline Other Ownership Spread & - & $\begin{array}{c}33.31 \\
(21.66)\end{array}$ & - \\
\hline Sample Size & 18600 & 7521 & 11079 \\
\hline
\end{tabular}

${ }^{a}$ Notes:

1. Data Source: Prowess, Centre for Monitoring Indian Economy (CMIE), for the years 1989-1999. All monetary variables are expressed in 1995 Rs. crore, where crore represents 10 million.

2. Standard deviations are in parentheses.

3. Operating Profit refers to manufacturing sales revenue minus total raw material expenses, energy expenses and wages and salaries. "Director Ownership Spread" is the difference between the minimum and maximum level of director ownership in a group; "Other Ownership Spread" is the difference between the minimum and maximum level of other ownership in a group. Ownership and ownership spread variables are measured in percentages and so range from 0 to 100 . 
Table 2:

Sensitivity to Own Shock: Group vs. Stand-Alone ${ }^{a}$

Dependent Variable: Profit Before DIT

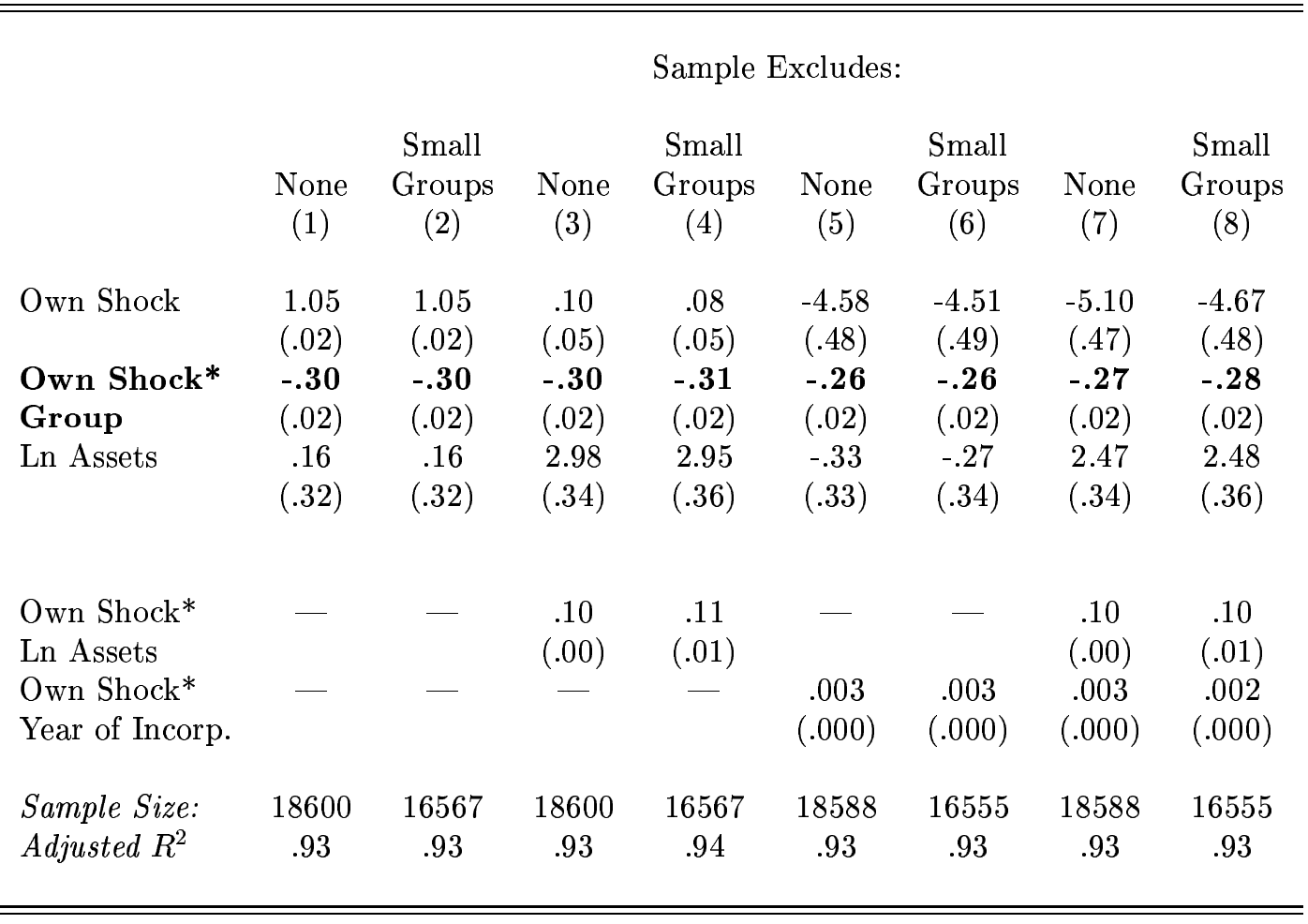

${ }^{a}$ Notes:

1. Data Source: Prowess, Center for Monitoring the Indian Economy, for years 1989-1999. All monetary variables are expressed in 1995 Rs. crore, where crore represents 10 million. Sample is composed of both stand-alone and group firms. "Small Groups" are groups that have less than 5 firms during the sampling period.

2. Standard errors are in parentheses.

3. All regressions include year fixed effects and firm fixed effects. 
Table 3:

Sensitivity to Own Shock by Director and Other Ownership ${ }^{a}$

Dependent Variable: Profit Before DIT

\section{Panel A: Director Ownership}

\begin{tabular}{lcccccc} 
& \multicolumn{7}{c}{ Sample Includes: } \\
& All & All & Large & Large & Stand- & Stand- \\
& Groups & Groups & Groups & Groups & Alones & Alones \\
& $(1)$ & $(2)$ & $(3)$ & $(4)$ & $(5)$ & $(6)$ \\
& & & & & & \\
Own Shock & .713 & -5.075 & .696 & -4.626 & 1.058 & -4.316 \\
& $(.009)$ & $(.742)$ & $(.011)$ & $(.820)$ & $(.006)$ & $(.518)$ \\
Own Shock* Director Equity &. $\mathbf{0 2 5}$ & .030 & .041 & .045 & .004 & .019 \\
& $(.003)$ & $(.003)$ & $(.004)$ & $(.004)$ & $(.001)$ & $(.001)$ \\
Own Shock*Ln Assets & - & .118 & - & .120 & - & .201 \\
& & $(.008)$ & & $(.009)$ & & $(.006)$ \\
Ln Assets & .052 & 4.261 & .573 & 5.557 & -.590 & 1.568 \\
& $(.733)$ & $(.807)$ & $(.945)$ & $(1.039)$ & $(.176)$ & $(.178)$ \\
Own Shock*Year of Incorp. & - & .002 & - & .002 & - & .002 \\
& & $(.000)$ & & $(.000)$ & & $(.000)$ \\
Sample Size: & 7521 & 7510 & 5488 & 5477 & 11079 & 11078 \\
Adjusted $R^{2}$ & .92 & .93 & .93 & .94 & .95 & .96 \\
& & & & & & \\
\hline \hline
\end{tabular}

Panel B: Other Ownership

Sample Includes:

All All Large Large Stand- Stand-

Groups Groups Groups Groups Alones Alones

$\begin{array}{llllll}(1) & (2) & (3) & (4) & (5)\end{array}$

Own Shock

$.919-5.764$

$.936 \quad-5.132$

$1.033-3.983$

$(.023) \quad(.743)$

$(.025) \quad(.825)$
-.008

Own Shock*Other Ownership

$-.007$

$-.007$

$-.008$

$-.008$

$(.052) \quad(.603)$

$(.001) \quad(.001)$
1.616

(.001)

$(.001)$

$.001 \quad .002$

Ln Assets

$1.616 \quad 5.189$

2.361

6.703

$(.000) \quad(.000)$

$(.724)$

$(.806)$

(.946)

(1.045)

$-.292$

2.049

Own Shock*Ln Assets

Own Shock*Year of Incorp.

\begin{tabular}{lccccc}
- & .103 & - & .108 & - & .154 \\
& $(.008)$ & & $(.009)$ & & $(.006)$ \\
- & .003 & - & .003 & - & .002 \\
& $(.000)$ & & $(.000)$ & & $(.000)$ \\
7521 & 7510 & 5488 & 5477 & 11079 & 11078 \\
.92 & .93 & .93 & .93 & .95 & .96 \\
& & & & & \\
\hline
\end{tabular}

${ }^{a}$ Notes:

Sample Size:

Adjusted $R^{2}$

1. Data Source: Prowess, Center for Monitoring the Indian Economy, for years 1989-1999. All monetary variables are expressed in 1995 Rs. crore, where crore represents 10 million. Sample is composed of both stand-alone and group firms. "Large Groups" excludes from the sample the groups who never have more than 5 firms during the sampling period.

2. Standard errors are in parentheses.

3. All regressions include year fixed effects and firm fixed effects. 
Table 4:

Sensitivity of Group Firms

to Group and Sub-Group Shocks ${ }^{a}$

Dependent Variable: Profit Before DIT

\begin{tabular}{|c|c|c|c|c|c|}
\hline & (1) & $(2)$ & (3) & $(4)$ & $(5)$ \\
\hline Own Shock & $\begin{array}{l}.730 \\
(.009)\end{array}$ & $\begin{array}{l}.732 \\
(.009)\end{array}$ & $\begin{array}{l}.732 \\
(.009)\end{array}$ & $\begin{array}{l}.732 \\
(.009)\end{array}$ & $\begin{array}{l}.732 \\
(.009)\end{array}$ \\
\hline Group Shock & $\begin{array}{l}.011 \\
(.001)\end{array}$ & - & - & - & - \\
\hline $\begin{array}{l}\text { Shock Below Median } \\
\text { (Director Equity) }\end{array}$ & - & $\begin{array}{l}.016 \\
(.002)\end{array}$ & - & - & - \\
\hline $\begin{array}{l}\text { Shock Above Median } \\
\text { (Director Equity) }\end{array}$ & - & $\begin{array}{l}-.002 \\
(.005)\end{array}$ & - & - & - \\
\hline $\begin{array}{l}\text { Shock Below 66th Pctile } \\
\text { (Director Equity) }\end{array}$ & - & - & $\begin{array}{l}.015 \\
(.002)\end{array}$ & - & - \\
\hline $\begin{array}{l}\text { Shock Above } 66 \text { th pctile } \\
\text { (Director Equity) }\end{array}$ & - & - & $\begin{array}{l}-.001 \\
(.001)\end{array}$ & - & - \\
\hline $\begin{array}{l}\text { Shock Below Median } \\
\text { (Other Ownership) }\end{array}$ & - & - & - & $\begin{array}{l}.014 \\
(.002)\end{array}$ & - \\
\hline $\begin{array}{l}\text { Shock Above Median } \\
\text { (Other Ownership) }\end{array}$ & - & - & - & $\begin{array}{l}.007 \\
(.004)\end{array}$ & - \\
\hline $\begin{array}{l}\text { Shock Below 33rd Pctile } \\
\text { (Other Ownership) }\end{array}$ & - & - & - & - & $\begin{array}{l}.017 \\
(.002)\end{array}$ \\
\hline $\begin{array}{l}\text { Shock Above 33rd Pctile } \\
\text { (Other Ownership) }\end{array}$ & - & - & - & - & $\begin{array}{l}-.002 \\
(.004)\end{array}$ \\
\hline Adjusted $R^{2}$ & $\begin{array}{c}.93 \\
7521\end{array}$ & $\begin{array}{c}.92 \\
7521\end{array}$ & $\begin{array}{c}.92 \\
7521\end{array}$ & $\begin{array}{c}.92 \\
7521\end{array}$ & $\begin{array}{c}.92 \\
7521\end{array}$ \\
\hline
\end{tabular}

\footnotetext{
${ }^{a}$ Notes:
}

1. Data Source: Prowess, Center for Monitoring the Indian Economy, for years 1989-1999. All monetary variables are expressed in 1995 Rs. crore, where crore represents 10 million.

2. Sample is only the group firms.

3. Also included in each regression are the logarithm of total assets, year fixed effects and firm fixed effects.

4. "Shock Below Median" is a variable that sums all the industry shocks to every firm in the same group (excluding the firm itself when applicable) that has below median ownership. holdings.

5. Standard errors are in parentheses. 
Table 5:

Sensitivity to Group Shock by Position in Group ${ }^{a}$

Dependent Variable: Profit Bef. DIT

\begin{tabular}{|c|c|c|c|c|c|c|c|c|}
\hline & $(1)$ & $(2)$ & (3) & (4) & (5) & $(6)$ & (7) & $(8)$ \\
\hline Level in Group: & Lower $\frac{2}{3}$ & Top $\frac{1}{3}$ & Below & Topmost & Firm & \multicolumn{3}{|c|}{ Topmost Firm } \\
\hline Own Shock & $\begin{array}{c}.62 \\
(.01)\end{array}$ & $\begin{array}{c}.89 \\
(.02)\end{array}$ & $\begin{array}{c}.63 \\
(.01)\end{array}$ & $\begin{array}{c}.63 \\
(.01)\end{array}$ & & $\begin{array}{l}1.01 \\
(.02)\end{array}$ & $\begin{array}{l}1.01 \\
(.02)\end{array}$ & $\begin{array}{l}1.01 \\
(.02)\end{array}$ \\
\hline Group Shock & $\begin{array}{l}.013 \\
(.002)\end{array}$ & $\begin{array}{c}.010 \\
(.002)\end{array}$ & $\begin{array}{l}.012 \\
(.001)\end{array}$ & - & - & $\begin{array}{c}.020 \\
(.008)\end{array}$ & - & - \\
\hline $\begin{array}{l}\text { Shock Below 66th Pctile } \\
\text { (Director Equity) }\end{array}$ & - & - & - & $\begin{array}{c}.015 \\
(.002)\end{array}$ & - & - & $\begin{array}{c}.032 \\
(.012)\end{array}$ & - \\
\hline $\begin{array}{l}\text { Shock Above 66th Pctile } \\
\text { (Director Equity) }\end{array}$ & - & - & - & $\begin{array}{l}.003 \\
(.006)\end{array}$ & & & $\begin{array}{c}.007 \\
(.018)\end{array}$ & - \\
\hline $\begin{array}{l}\text { Shock Below 33rd Pctile } \\
\text { (Other Ownership) }\end{array}$ & - & - & - & - & $\begin{array}{l}-.000 \\
(.004)\end{array}$ & - & - & $\begin{array}{l}-.013 \\
(.025)\end{array}$ \\
\hline $\begin{array}{l}\text { Shock Above 33rd Pctile } \\
\text { (Other Ownership) }\end{array}$ & 一 & - & - & - & $\begin{array}{l}.017 \\
(.002)\end{array}$ & 一 & 一 & $\begin{array}{l}.034 \\
(.011)\end{array}$ \\
\hline Sample Size & 4905 & 2616 & 5780 & 5780 & 5780 & 1741 & 1741 & 1741 \\
\hline Adjusted $R^{2}$ & .90 & .95 & .90 & .97 & .97 & .97 & .97 & .97 \\
\hline
\end{tabular}

${ }^{a}$ Notes:

1. Data Source: Prowess, Center for Monitoring the Indian Economy, for years 1989-1999. All monetary variables are expressed in 1995 Rs. crore, where crore represents 10 million.

2. Sample is only the group firms.

3. Also included in each regression are the logarithm of total assets, year fixed effects and firm fixed effects.

4. Firms are separated into different "Levels in Group" based on their within-group level of director equity.

5. Standard errors are in parentheses. 
Table 6:

Differences in Diversification ${ }^{a}$

\begin{tabular}{|c|c|c|c|c|c|c|}
\hline \multirow{2}{*}{ Groups } & \multirow{2}{*}{\multicolumn{2}{|c|}{$\begin{array}{ll}\text { All Stand- } \\
\\
\text { Alones }\end{array}$}} & \multicolumn{2}{|c|}{ Director's equity } & \multicolumn{2}{|c|}{ Other Equity } \\
\hline & & & $\begin{array}{l}\text { High in } \\
\text { Group }\end{array}$ & $\begin{array}{l}\text { Low in } \\
\text { Group }\end{array}$ & $\begin{array}{l}\text { High in } \\
\text { Group }\end{array}$ & $\begin{array}{l}\text { Low in } \\
\text { Group }\end{array}$ \\
\hline 2 Digit & $.88^{*}$ & $.92^{*}$ & .88 & .88 & .88 & .88 \\
\hline Herfindahl & $(.19)$ & $(.15)$ & $(.18)$ & $(.18)$ & $(.18)$ & $(.18)$ \\
\hline $\begin{array}{l}\text { Regression } \\
\text { Adjusted }\end{array}$ & \multicolumn{2}{|c|}{$\begin{array}{l}.005 \\
(.010)\end{array}$} & \multicolumn{2}{|c|}{$\begin{array}{l}-.011 \\
(.013)\end{array}$} & \multicolumn{2}{|c|}{$\begin{array}{c}-.006 \\
(.013)\end{array}$} \\
\hline 12 Digit & $.69^{*}$ & $.74^{*}$ & .69 & .69 & .67 & .70 \\
\hline $\begin{array}{l}\text { Regression } \\
\text { Adjusted }\end{array}$ & \multicolumn{2}{|c|}{$\begin{array}{l}.034^{*} \\
(.016)\end{array}$} & \multicolumn{2}{|c|}{$\begin{array}{l}.004 \\
(.020)\end{array}$} & \multicolumn{2}{|c|}{$\begin{array}{c}.034 \\
(.020)\end{array}$} \\
\hline $\begin{array}{l}2 \text { Digit } \\
\text { Product Count }\end{array}$ & $\begin{array}{l}2.11^{*} \\
(1.44)\end{array}$ & $\begin{array}{l}1.58^{*} \\
(.86)\end{array}$ & $\begin{array}{c}2.11 \\
(.028)\end{array}$ & $\begin{array}{c}2.10 \\
(.020)\end{array}$ & $\begin{array}{c}2.13 \\
(1.42)\end{array}$ & $\begin{array}{c}2.09 \\
(1.44)\end{array}$ \\
\hline $\begin{array}{l}\text { Regression } \\
\text { Adjusted }\end{array}$ & \multicolumn{2}{|c|}{$\begin{array}{c}.041 \\
(.048)\end{array}$} & \multicolumn{2}{|c|}{$\begin{array}{l}-.063 \\
(.083)\end{array}$} & \multicolumn{2}{|c|}{$\begin{array}{l}.014 \\
(.086)\end{array}$} \\
\hline $\begin{array}{l}12 \text { Digit } \\
\text { Product Count }\end{array}$ & $\begin{array}{l}4.62^{*} \\
(4.31)\end{array}$ & $\begin{array}{c}3.0^{*} \\
(2.15)\end{array}$ & $\begin{array}{c}4.84 \\
(4.08)\end{array}$ & $\begin{array}{c}4.51 \\
(4.75)\end{array}$ & $\begin{array}{c}4.79 \\
(4.33)\end{array}$ & $\begin{array}{c}4.54 \\
(4.30)\end{array}$ \\
\hline $\begin{array}{l}\text { Regression } \\
\text { Adjusted }\end{array}$ & \multicolumn{2}{|c|}{$\begin{array}{l}-.005 \\
(.010)\end{array}$} & \multicolumn{2}{|c|}{$\begin{array}{l}-.274 \\
(.327)\end{array}$} & \multicolumn{2}{|c|}{$\begin{array}{l}-.168 \\
(.322)\end{array}$} \\
\hline
\end{tabular}

\footnotetext{
${ }^{a}$ Notes:

1. Data Source: Prowess, Center for Monitoring the Indian Economy, for years 1989-1999.

2. For each diversification measure, the first two rows contain means and standard deviations for each diversification measure. The second two rows contain the relevant coefficient and standard errors from a regression which includes year dummies, logarithm of total assets and industry fixed effects. A "*" indicates that the difference in means is statistically significant at the $5 \%$ level.

3. "High in Group" and "Low in Group" refer to the firms above and below median director equity (columns 3 and 4 ) and to the firms below and above median other ownership (columns 5 and 6 ), respectively.

4. Two digit and twelve digit product codes are described in the text.
} 
Table 7: Sensitivity to Own Shock

Robustness Checks ${ }^{a}$

Dependent Variable: Profit Before DIT

\begin{tabular}{|c|c|c|c|c|}
\hline & (1) & (2) & (3) & (4) \\
\hline Own Shock & $\begin{array}{l}.641 \\
(.049)\end{array}$ & $\begin{array}{l}.765 \\
(.012)\end{array}$ & $\begin{array}{l}.713 \\
(.010)\end{array}$ & $\begin{array}{l}.736 \\
(.010)\end{array}$ \\
\hline Own Shock*Director Equity & $\begin{array}{l}.025 \\
(.003)\end{array}$ & $\begin{array}{l}.026 \\
(.003)\end{array}$ & $\begin{array}{l}.025 \\
(.003)\end{array}$ & $\begin{array}{l}.022 \\
(.003)\end{array}$ \\
\hline $\begin{array}{l}\text { Own Shock* } \\
\text { Industry Cash Richness }\end{array}$ & $\begin{array}{l}.490 \\
(.328)\end{array}$ & - & 一 & - \\
\hline $\begin{array}{l}\text { Own Shock* } \\
\text { Total Group Lending }\end{array}$ & - & $\begin{array}{l}-22.01 \\
(2.84)\end{array}$ & - & - \\
\hline $\begin{array}{l}\text { Own Shock* } \\
\text { Firm's Lending from Group }\end{array}$ & - & - & $\begin{array}{c}-3.83 \\
(10.70)\end{array}$ & - \\
\hline $\begin{array}{l}\text { Own Shock* } \\
\text { Firm's Lending to Group }\end{array}$ & - & - & - & $\begin{array}{l}-1.89 \\
(.19)\end{array}$ \\
\hline $\begin{array}{l}\text { Sample Size } \\
\text { Adjusted } R^{2}\end{array}$ & $\begin{array}{l}7482 \\
.92\end{array}$ & $\begin{array}{l}7521 \\
.93\end{array}$ & $\begin{array}{l}7445 \\
.92\end{array}$ & $\begin{array}{c}7445 \\
.93\end{array}$ \\
\hline
\end{tabular}

${ }^{a}$ Notes:

1. Data Source: Prowess, Center for Monitoring the Indian Economy, for years 1989-1999. All monetary variables are expressed in 1995 Rs. crore, where crore represents 10 million.

2. Sample includes both stand-alone and group firms.

3. Also included in each regression are the logarithm of total assets, year fixed effects, firm fixed effects and all relevant direct effects for the interction terms.

4. "Industry Cash Richness" is the average of profit before DIT to total assets ratio in the firm's industry in the base year (1989). "Total Group Lending" is the ratio of total loans from group firms to total assets in the firm's group over the entire sample period. "Firm's Lending from Group" is the ratio of loans from group firms to total assets for that firm in that year. "Firm's Lending to Group" is the ratio of loans to group firms to total assets for that firm in that year.

5. Also included in each regression are the logarithm of total assets, year fixed effects and firm fixed effects and, when relevant, the direct effect of the interaction terms.

6. Standard errors are in parentheses. 
Table 8: Shock Sensitivity

An Accounting Decomposition ${ }^{a}$

\section{Panel A: Sensitivity to Own Shock}

Sample Includes:

$\begin{array}{lcc} & \begin{array}{c}\text { All } \\ \text { Groups }\end{array} & \begin{array}{c}\text { Stand- } \\ \text { Alones }\end{array} \\ \text { Dep. Var.: } & & \\ & & \\ \text { Operating Profits } & 1.22 & 1.17 \\ & (.018) & (.009) \\ \text { Non-Operating Profits } & -.478 & -.103 \\ & (.014) & (.006)\end{array}$

Panel B: Sensitivity to Own Shock by Level in Group

Sample Includes:

$\begin{array}{lcc} & \text { All } & \text { Stand- } \\ & \text { Groups } & \text { Alones } \\ \text { Dep. Var.: } & & \\ \text { Operating Profits } & .0123 & .0082 \\ & (.0056) & (.0013) \\ \text { Non-Operating Profits } & .0131 & -.0038 \\ & (.0043) & (.0008)\end{array}$

Panel C: Sensitivity to Group Shock by Level in Group

Sample Includes:

$\begin{array}{lcc} & \text { Top Only } & \text { Below Top } \\ \text { Dep. Var.: } & & \\ \text { Operating Profits } & .0066 & .0114 \\ & (.0128) & (.0026) \\ \text { Non-Operating Profits } & .0134 & .0006 \\ & (.0078) & (.0020)\end{array}$

\footnotetext{
${ }^{a}$ Notes:

1. Data Source: Prowess, Center for Monitoring the Indian Economy, for years 1989-1999. All monetary variables are expressed in 1995 Rs. crore, where crore represents 10 million.

2. Each coefficient contains the result of a separate regression in which the dependent variable is either operating profits or non-operating profits, as indicated.

3. In Panel A, the reported coefficient is the coefficient on "Own Shock." In Panel B, the reported coefficient is the coefficient on "Own Shock" interacted with the director ownership variable. In Panel C, the reported coefficient is the coefficient on "Group Shock." Also included in each regression are the logarithm of total assets, year fixed effects, firm fixed effects and the direct effects of the interaction terms.

4. Sample used is as noted in Panels A and B. In Panel C, the subsamples are from group firms aonly. Top firm and below top firms are defined using director's equity.

5. Standard errors are in parentheses.
} 
Table 9:

Sensitivity to Own and Group Shocks

by Firm and Group Q Ratios ${ }^{a}$

Dependent Variable: Profit Before DIT

\begin{tabular}{lcccc}
\hline \hline & $(1)$ & $(2)$ & $(3)$ & $(4)$ \\
& & & & \\
Own Shock & -.046 & .388 & .600 & .049 \\
& $(.056)$ & $(.027)$ & $(.017)$ & $(.060)$ \\
Own Shock*Firm Q & .178 & - & & .143 \\
& $(.013)$ & & & $(.016)$ \\
Own Shock*Relative Q & - & .143 & - & - \\
& & $(.011)$ & & \\
Own Shock*Group Q & - & - & .414 & .171 \\
& & & $(.037)$ & $(.044)$ \\
& & & & \\
Group Shock & -.008 & .010 & .011 & -.008 \\
& $(.003)$ & $(.002)$ & $(.003)$ & $(.004)$ \\
Group Shock*Firm Q & .012 & - & - & .012 \\
& $(.001)$ & & & $(.001)$ \\
Group Shock*Relative Q & - & .008 & - & - \\
Group Shock*Group Q & - & $(.001)$ & & \\
& & & .006 & -.001 \\
Adjusted $R^{2}$ & & & $(.007)$ & $(.006)$ \\
\hline \hline
\end{tabular}

${ }^{a}$ Notes:

1. Data Source: Prowess, Center for Monitoring the Indian Economy, for years 1989-1999. All monetary variables are expressed in 1995 Rs. crore, where crore represents 10 million.

2. Sample is only the group firms (7521 firms).

3. Also included in each regression are the logarithm of total assets, year fixed effects, firm fixed effects and all relevant direct effects for the interction terms.

4. "Firm Q" is a variable that represents the estimated firm fixed effects in a regression of firm-level q ratios on log(total assets), year fixed effects, industry fixed effects and firm fixed effects. "Group Q" is a variable that represents the estimated group fixed effects in a regression of firm-level q ratios on $\log$ (total assets), year fixed effects, industry fixed effects and group fixed effects. "Relative Q" is the difference between "Firm Q" and mean of "Firm Q" within groups.

5. Also included in each regression are the logarithm of total assets, year fixed effects and firm fixed effects and, when relevant, the direct effect of the interaction terms.

6. Standard errors are in parentheses. 


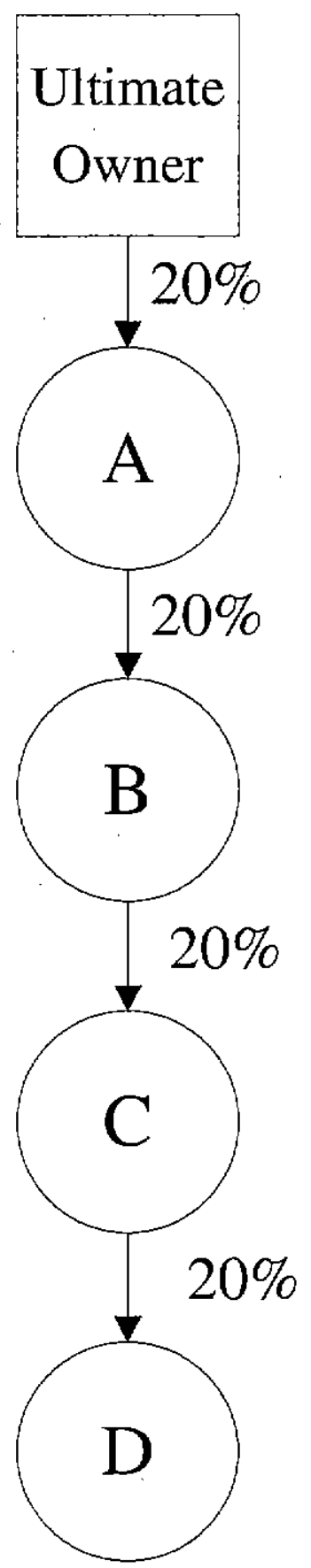

Figure 1: Example of Pyramid

Arrows indicate direction of ownership 